\title{
INSTITUTIONAL ROLE IN RELATION TO LEGAL POLICY TOWARDS OF CHILDREN'S RIGHTS TO EXCLUSIVE BREASTFEEDING
}

\section{Lenny Syahnimar}

Dinas Kesehatan Kota Bandar Lampung, Indonesia, Email: lenny.syahnimar@gmail.com

Submitted: January 6, 2020; Reviewed: January 28, 2020; Accepted: February 3, 2020

\begin{tabular}{ll}
\hline \multicolumn{1}{c}{ Article Info } & \multicolumn{1}{c}{ Abstract } \\
\hline Keywords: & Breastfeeding is one of the best buys in global health to \\
Breastfeeding, Institution, & save lives and improve the health, social, and economic \\
Support. & development of individuals and nations. Inadequate \\
breastfeeding impacts a child's ability to learn, and & consequently, their future earning potential. By \\
DOI: & supporting mothers to practice proper breastfeeding, \\
10.25041/lajil.v2i1.2029 & nearly 50 per cent of under two child deaths caused by \\
& diarrhoea and pneumonia could be prevented annually \\
& compared to a situation with no breastfeeding. This study \\
& aims to understand and analyze the role institutions and \\
& legal policy towards the fulfilment of children's rights to \\
& exclusive breastfeeding. This research is normative- \\
empirical legal research. Primary data was obtained & through interviews with sources, while secondary data is \\
attained through literature studies on legal material. Data \\
analysis is carried out with a qualitative approach. \\
Results: Institutional is a set of rules of all levels that \\
revolve around a fundamental need in the social life of \\
society. The institutional role is to meet the basic needs \\
of citizens regarding an order, guidelines on how to \\
behave, and as social control. Legal rule the exclusive \\
Nursing program policy is based on the provisions of the \\
Law No. 36 of 2009 with the form of regulation through \\
Government Regulations No. 33 of 2012.
\end{tabular}

\section{A. Introduction}

Breastfeeding is an ideal nutrient to support the health, growth, and development of babies. Babies are recommended to be exclusively breastfed during the first six months and continued with complementary foods in their first two years of life. ${ }^{1}$ Various studies have shown that breastfeeding provides many physiological and emotional benefits. ${ }^{2}$ The benefits of

\footnotetext{
${ }^{1}$ Badriul Hegar, Nilai Menyusui (2010), 1-12, in IDAI, Indonesia Menyusui (Jakarta: Badan Penerbit IDAI), 1-2.

${ }^{2}$ Edelwina Umboh, Rocky Wilar, Max F. J. Mantik, "PENGETAHUAN IBU MENGENAI MANFAAT ASI PADA BAYI”, Jurnal e-Biomedik (eBM) 1, no. 1, (2013): 210-214, 211.
} 
breastfeeding for babies are breast milk has optimal nutrition, both in quantity and quality. ${ }^{3}$ Furthermore, it is always available in a clean condition, anytime and in the right temperature of the mother's breast, easily digested and absorbed by the body. ${ }^{4}$ Breastfeeding benefits the mother by managing fertility, reducing the risk of osteoporosis, ovarian cancer, and breast cancer, and type II diabetes. ${ }^{5}$ In addition, breastfeeding helps mothers gain back the weight as it was before, reduce postpartum bleeding. ${ }^{6}$ Moreover, breastfeeding benefits families and society (environment) such as reducing poverty and hunger, and reduce the cost of health care budgets. $^{7}$

UNICEF states that the exclusive breastfeeding (no food or extra drinks for the babies) it should be able to prevent the death of 30,000 infants in Indonesia and 10 million toddlers in the world each year. Lancet, in 2010, emphasized this statement as well on his research by arguing that exclusive breastfeeding could cut infant mortality by $13 \%$ and the prevalence of stunting. ${ }^{8}$ Stunting is a failed condition of a toddler to grow because of the chronic malnutrition. Thus, the height is not ideal for their age. ${ }^{9}$ Stunting occurs because of the impact of chronic malnutrition in the first 1,000 days of a child's life, and exclusive breastfeeding is not given to the baby. ${ }^{10}$ Current studies show that stunting is strongly associated with poor educational performance, decreased education duration and low-income as adults. ${ }^{11}$ Therefore, stunting children are a predictor of the poor quality of widely accepted human resources, which in turn decreases the productive capacity of a nation in the future. ${ }^{12}$

The level of exclusive breastfeeding based on Riskesdas in 2010 was only 15.3 per cent. ${ }^{13}$ Riskesdas in 2013 increased to $30.2 \%{ }^{14}$ and 2018 by 37.3\% ${ }^{15}$ Nurhira Abdul Kadir classified the causes of the low percentage of exclusive breastfeeding in Indonesia in two problems, namely internal problems and external problems. Internal problems consist of physical problems, psychological problems, delayed early breastfeeding initiation, and mother's work and education. At the same time, obvious problems include family problems, food security,

3 Yusuf Hanafi, "PENINGKATAN KECERDASAN ANAK MELALUI PEMBERIAN ASI DALAM ALQUR'AN", Mutawâtir: Jurnal Keilmuan Tafsir Hadis 2, no. 1 (2012): 27-45, 28, DOI: 10.15642/mutawatir.2012.2.1.27-45.

${ }^{4}$ F.B. Monika, Buku Pintar ASI dan Menyusui (Jakarta: Noura Books, 2014), 6.

${ }^{5}$ Putri Nilam Sari, "MENINGKATKAN KESUKSESAN PROGRAM ASI EKSKLUSIF PADA IBU BEKERJA SEBAGAI UPAYA PENCAPAIAN MDGS”, Jurnal Kesehatan Masyarakat Andalas 9, no. 2 (2015): 93-97, 94, DOI: $10.24893 / \mathrm{jkma} . \mathrm{v} 9 \mathrm{i} 2.194$.

${ }^{6}$ Maria Pollard, ASI Asuhan Berbasis Bukti (Jakarta: EGC, 2015), 4.

${ }^{7}$ F.B. Monika, Op.Cit., 9-10.

${ }^{8}$ Kementerian Kesehatan RI, Pokok-pokok Peraturan Pemerintah No. 33 Tahun 2012 tentang Pemberian Air Susu Ibu Eksklusif (Jakarta: Kementerian Kesehatan RI, 2012), 7.

9 Tim Nasional Percepatan Penanggulangan Kemiskinan (TNP2K), 100 Kabupaten/Kota Prioritas untuk Intervensi Anak Kerdil (Stunting) Ringkasan (Jakarta: Tim Nasional Percepatan Penanggulangan Kemiskinan, 2017), 2.

${ }^{10}$ Farah Okky Aridiyah, Ninna Rohmawati, Mury Ririanty, "FAKTOR-FAKTOR YANG MEMPENGARUHI KEJADIAN STUNTING PADA ANAK BALITA DI WILAYAH PEDESAAN DAN PERKOTAAN”, e-Jurnal Pustaka Kesehatan 3, no. 1 (2015): 163-170, 165.

${ }^{11}$ Eko Setiawan, Rizanda Machmud, Masrul, "FAKTOR-FAKTOR YANG BERHUBUNGAN DENGAN KEJADIAN STUNTING PADA ANAK USIA 24-59 BULAN DI WILAYAH KERJA PUSKESMAS ANDALAS KECAMATAN PADANG TIMUR KOTA PADANG TAHUN 2018”, Jurnal Kesehatan Andalas 7, no. 2 (2018): 275-284, 276, DOI: 10.25077/jka.v7i2.813.

${ }^{12}$ Trihono, Pendek (Stunting) di Indonesia, Masalah dan Solusinya (Jakarta: Badan Penelitian dan Pengembangan Kesehatan, 2015), 1-2.

${ }^{13}$ Kementerian Kesehatan, Op.Cit., 6-7.

${ }^{14}$ Badan Penelitian dan Pengembangan Kesehatan, Riskesdas 2013 (Jakarta: Kementerian Kesehatan RI, 2013), iv.

${ }^{15}$ Badan Penelitian dan Pengembangan Kesehatan, Hasil Utama Riskesdas Tahun 2018 (Jakarta: Kementerian Kesehatan RI, 2018), 44. 
geographical area, the role of media, water, hygiene and sanitation, health professionals, poverty, cultural beliefs and practices, and government involvement. ${ }^{16}$ Given the variety of goodness in breastfeeding, the government has provided legal protection through Law No. 36 of 2009 Article $128 .{ }^{17}$ Government involvement is the key to build a conducive breastfeeding situation. ${ }^{18}$ In addition, the right to breastfeed for women workers has been regulated by Article 83 of Law No.13 / 2003 actually have sufficiently accommodated ILO Convention No. 183 of 2000 concerning Maternity. ${ }^{19}$

Breastfeeding is the right of every mother, including working mothers, as well as children's rights, which are guaranteed by the Constitution. ${ }^{20}$ The child's right to survive is specifically regulated in Article 28B Paragraph (2) of the 1945 Constitution. ${ }^{21}$ National regulations actually guarantee the rights of women, such as breastfeeding rights. But in some cases, these rights are not properly implemented or non-fulfillment of the right of the child to get breastfeed. ${ }^{22}$ The problem of not fulfilling the right of the baby in obtaining exclusive breastfeeding has come to the attention of the World Health Organization (WHO) and also the Indonesian government, bearing in mind the interests of the baby in getting exclusive breastfeeding, it is necessary to obtain legal protection. ${ }^{23}$

Breastfeeding is one of the first steps for a human being to get a healthy and prosperous life. ${ }^{24}$ When the babies have been born, breast milk and other primary health services are mandatory to liberate the children from the possibility of disability and disease. ${ }^{25}$ The legal function is a social institution, namely a set of rules from all levels that revolve around a basic need in the social life of the community. It is as a result of the purpose of the law, namely to fulfil the basic needs of the community in order and as a social institution. Thus, the law serves as a guideline on how to behave, as a tool to safeguard people's needs and as social control. ${ }^{26}$ The institution is one of the government institutions responsible for the success of the exclusive

\footnotetext{
${ }^{16}$ Nurhira Abdul Kadir, "MENELUSURI AKAR MASALAH RENDAHNYA PERSENTASE PEMBERIAN ASI EKSKLUSIF DI INDONESIA”, Jurnal Al Hikmah 15, no. 1 (2014): 106-118, 108- 113.

${ }^{17}$ Tuti Haryanti, Nurhayati, "PENEGAKAN HUKUM HAK ASASI MANUSIA BAGI ANAK PENDERITA STUNTING", Jurnal HAM 10, no. 2 (2019): 249-260, 256, DOI: 10.30641/ham.2019.10.249-260.

${ }^{18} \mathrm{Ibid}, 114$.

${ }^{19}$ H Marlia Eka Putri A.T, "TINJAUAN ATAS PERLINDUNGAN HUKUM TERHADAP HAK MENYUSUI ANAK SELAMA WAKTU KERJA DI TEMPAT KERJA BAGI PEKERJA PEREMPUAN”, Fiat Justisia: Jurnal Ilmu Hukum 5, no. 3 (2011): 307-314, DOI: 10.25041/fiatjustisia.v5no3.331.

${ }^{20}$ Herning Hambarrukmi, Triana Sofiani, "KEBIJAKAN PEMBERIAN ASI EKSKLUSIF BAGI PEKERJA PEREMPUAN DI INDONESIA", MUWAZAH 8, no. 2 (2016): 268-286, 268.

${ }^{21}$ Saldi Isra, "PERAN MAHKAMAH KONSTITUSI DALAM PENGUATAN HAK ASASI MANUSIA DI INDONESIA", Jurnal Konstitusi 11, no. 3 (2014): 409-427, 416, DOI: 10.31078/jk\%25x.

${ }^{22}$ Sulthon Miladiyanto, Ariyanti, "PERLINDUNGAN HUKUM TERHADAP HAK-HAK REPRODUKSI PEKERJA WANITA (PERSPEKTIF UNDANG-UNDANG KETENAGAKERJAAN DI INDONESIA DAN MALAYSIA)", Jurnal Panorama Hukum 2, no. 1 (2017): 53-68, 61, DOI: 10.21067/jph.v2i1.1755.

${ }^{23}$ Edy Nurcahyo, Siti Khuzaiyah, "PERLINDUNGAN HUKUM BAYI MELALUI PEMBERIAN ASI EKSKLUSIF DALAM PRESPEKTIF UNDANG-UNDANG NOMOR 36 TAHUN 2009 TENTANG KESEHATAN", Jurnal Cendekia Hukum 4, no 1 (2018): 52-64, 54, DOI: 10.33760/jch.v4i1.59.

${ }^{24}$ Yanik Muyassaroh, Rizky Amelia, Komariyah, "FAKTOR PENGHAMBAT PEMBERIAN ASI EKSKLUSIF PADA IBU BEKERJA DI KOTA BLORA", Jurnal Kebidanan 8, no. 1 (2018): 10-21, 10, DOI:10.31983/jkb.v8i1.3730.

${ }^{25}$ Maidin Gultom, Perlindungan Hukum Terhadap Anak dan Perempuan (Bandung: Refika Aditam, 2013): 7072 .

${ }^{26}$ Zainuddin Ali, Metode Penelitian Hukum (Jakarta: Sinar Grafika, 2016), 124.
} 
breastfeeding program. ${ }^{27}$ All existing institutions should be seen as part of the whole legal system that needs to be developed within the framework of the Indonesian rule of law. ${ }^{28}$

Therefore, it is necessary to discuss the role of institutions in law enforcement in fulfilling the right of children to obtain exclusive breastfeeding. In current law enforcement practices, it is still common for law enforcement officials to use their authority. ${ }^{29}$ This study aims to understand and analyze the role of institutions in relation to legal policy towards the fulfilment of children's rights to exclusive breastfeeding. This research is normative-empirical legal research. Normative legal research is based on data obtained from literature studies. Empirical legal research is by obtaining primary data in the form of interviews and observations supported by secondary data. ${ }^{30}$ Data analysis is carried out with a qualitative approach.

\section{B. Discussion}

Community institutions are a set of norms of all levels that revolve around a basic need in the social life of the community. ${ }^{31}$ This means as a procedure that has been created to regulate human relations in groups in a social group commonly called associations. ${ }^{32}$ Therefore, social institutions when viewed from their functions can be interpreted as a network of human relations processes, between human groups that function to maintain the relationship, and patterns according to the interests of humans and their groups. ${ }^{33}$ Social institutions are made and created as facilities to help the creation of fulfilment of the needs of the members of the community concerned. In order to fulfil the needs to run smoothly, the community provides a container that allows all processes to run regularly. Provision of these containers, through rules, develops values related to meet certain needs. Therefore, social institutions try to fulfil basic needs in an orderly and orderly manner. ${ }^{34}$

Based on the understanding of institutions, social institutions, and social institutions above, Zainuddin Ali considers law as a social institution, which is a set of rules from all levels that revolve around a basic need in the social life of the community. This is as a result of the purpose of the law to fulfil the basic needs of citizens with regard to order, and as a social institution, hence, the law serves as a guideline on how to behave, as a tool to safeguard people's needs and as social control. ${ }^{35}$ Besides, according to Joseph Raz, the primary social, legal function

\footnotetext{
27 Angga Sisca Rahadian, "PEMENUHAN HAK ASI EKSKLUSIF DI KALANGAN IBU BEKERJA: PELUANG DAN TANTANGAN”, Jurnal Kependudukan Indonesia 9, no. 2 (2014): 109-119, 3, DOI: 10.14203/jki.v9i2.40.

${ }^{28}$ Dedi Sumanto, "PENEGAKAN HUKUM DAN PEMBANGUNAN HUKUM DI INDONESIA", Jurnal AlMizan 10, no. 1 (2014): 121-139, 123.

${ }^{29}$ Zahri Kurniawan, Ilham Wahyudi, and H S Tisnanta, "THE RIGHT NON-SELF-INCRIMINATION AND EPISTEMOLOGY OF CRIMINAL WITNESSES,” Fiat Justisia: Jurnal Ilmu Hukum 14, no. 4 (2020): 363-380, 364, DOI: 10.25041/fiatjustisia.v14vno4.1988.

${ }^{30}$ Felishella Earlene, Jesslyn Evelina Tandrajaya, "SENGKETA PENGUASAAN TANAH ANTARA WARGA KAPUK POGLAR RT 07/RW 04 JAKARTA BARAT DENGAN POLDA METRO JAYA DITINJAU DARI PERSPEKTIF HAK ASASI MANUSIA", Jurnal Cepalo 3, no. 2 (2019): 52-62, 57, DOI: 10.25041/cepalo.v3no2.1844.

31 Sri Wulandari, "PERAN BADAN PERENCANAAN PEMBANGUNAN DAERAH DALAM PELAKSANAAN MUSRENBANG DI KOTA TARAKAN”, eJournal Administrasi Negara 1, no. 4 (2013): 111,1 .

${ }^{32}$ Frangky Benjamin Kandioh, Johny Lumolos, Markus Kaunang, "EKSISTENSI KELOMPOK- KELOMPOK SOSIAL DALAM MELESTARIKAN NILAI-NILAI BUDAYA DI DESA KAMANGTA KECAMATAN TOMBULU KABUPATEN MINAHASA", Society Jurnal Ilmu Sosial dan Pengelolaan Sumber Daya Pembangunan 21, no. 1 (2016): 49-62, 54.

${ }^{33}$ Soerjono Soekanto, Sosiologi Suatu Pengantar (Jakarta: Rajawali Press, 1990), 218, in Zainuddin Ali, Op.Cit., 123-124.

${ }^{34}$ Satjipto Rahadjo, Ilmu Hukum (Bandung: Alumni, 1982), 31, in Zainuddin, Op.Cit., 124.

${ }^{35}$ Zainuddin Ali, Loc.Cit.
} 
directly in the prevention of certain actions, encouraging certain actions and providing facilities for private plans. ${ }^{36}$

The institutional objective of making legislation is to maintain and observe all structures and processes related to the activities and efforts to realize the fulfilment of the need for legislation on the one hand and efforts to facilitate the fulfilment of needs on the other side. Good legislation reflects juridical, sociological and philosophical aspects. This means creating a statutory regulation that gets the right place and influence so that it can be adhered to by the citizens of the community spontaneously and not by force because it fits the legal culture adopted by the citizens. ${ }^{37}$ These are by the national legal politics contained in the Decree of the MPR No. II/MPR/1993 concerning the Guidelines of State Policy, especially in the field of law, namely: in the formation of law it is necessary to heed provisions that fulfil philosophical values which have a sense of justice and truth, sociological values that are by the cultural values prevailing in society and juridical value in accordance with the provisions of the applicable legislation.

In the preparation of Government Regulation Number 33 of 2012, there are three foundations, namely: philosophical foundation, sociological foundation, and juridical foundation.

\section{Philosophical Foundation}

Health is a human right and one of the elements of welfare that must be realized in accordance with the ideals of the Indonesian people as intended in Pancasila and the 1945 Constitution of the Republic of Indonesia. Human rights and the right of babies to obtain breast milk are protected in the Indonesian Constitution and several laws and regulations. Even though many babies who do not get breast milk and become victims of violence and human rights violations still occur in the life of society, nation, and state. As a result of low levels of education, low health facilities and socio-cultural influences that still place women and babies in vulnerable groups, maternal and child mortality rates are still high. As long as there are no clear rules to protect the rights of women working in factories, animal husbandry, and agriculture, how can they still exercise their rights and fulfil their breastmilk needs? Government regulations on breastfeeding are formed in order to provide protection for babies to get their rights to exclusive breastfeeding.

\section{Sociological Platform}

The best pattern of feeding for babies from birth to 2-year-old children as recommended by WHO and UNICEF or known as the Global Strategy of Infant and Young Child Feeding (GSIYCF) often called Standard Gold feeding in infants and children, includes: (1) giving breast milk to the baby immediately within one hour after birth; (2) giving only breast milk from birth to 6 months of age (exclusive breastfeeding); (3) providing complimentary food, which is exactly six months old; and (4) continue breastfeeding until the child is two years or older. The application of this feeding pattern will improve the nutritional status of infants and children and influence subsequent health status. Unfortunately, right now, the implementation of the best feeding pattern recommendations has not been appropriately implemented, particularly in the case of 6 months of exclusive breastfeeding. Some of the reasons the low rates of exclusive breastfeeding are: (1) social conditions of the community where the mother has low confident on her ability to breastfeed her baby, thus the baby's nutritional needs are sufficient; (2) lack of knowledge of the mother, lack of family support, traditions and/or culture that can inhibit breastfeeding, as well as low public awareness about the benefits of exclusive

\footnotetext{
${ }^{36}$ Zaeni Asyihadie and Arief Rahman, Pengantar Ilmu Hukum, Ed.1 (Jakarta: Rajawali Pers, 2013), 132.

${ }^{37}$ Zainuddin Ali, Op.Cit., 125.
} 
breastfeeding; (3) lack of support from health workers, health service facilities, as well as from employers and service providers of public and special facilities; and (4) the influences of improper promotions from producers of baby food and drinks and other baby products. The Government Regulation on breastfeeding strengthens the exclusive breastfeeding activities for babies and the activities of health cadres in Posyandu and Puskesmas. The cadres encourage the mothers to breastfeed for the first six months exclusively and breastfeed, accompanied by natural food and/or home cooking, until the baby two years old.

\section{Juridical Platform}

Based on these philosophical and sociological, the Government is responsible for establishing the policies in order to guarantee the rights of infants and children to obtain breast milk. As the outcome, the Government issued the regulation of breastfeeding in Law Number 36 of 2009 Article 128Its Article 129 regulates the technical issue of Article 128. Furthermore, to follow-up article 129, the Government has issued Government Regulation No. 33 of 2012 on March 1, 2012. ${ }^{38}$

\section{Legal Basis for Compiling Written Policies on Exclusive Breastfeeding}

a. International Labor Organization Convention (ILO) Number 183/2000 about the Revision of The Convention on Maternity Protection (Revised 1952)

Under Article 10 of the International Labor Organization Convention (ILO) Number $183 / 2000$, the state must support \& guarantee the activity of breastfeeding mothers' rights. This Article regulates that: ${ }^{39}$

1) Women must be given the right to daily rest or a reduction in daily work hours to breastfeed their children.

2) How long a breastfeeding break or a reduction in daily work hours will be given, how many in a day, each time these breaks and methods of reducing daily work hours are regulated according to national law and practice. Rest and reduction of daily work hours must be counted as work hours and paid for.

International Labor Organization Convention (ILO) Number 183/2000 aims at equality of women as workers and ensuring the health and safety of mothers and children in various industries. Indonesia did not specifically ratify this convention because its contents have been accommodated in national provisions, namely in Law Number 13 of 2003 concerning Labour. ${ }^{40}$

\section{b. Legal Basis, namely the 1945 Constitution of the Republic of Indonesia}

1) Article 28 B paragraph (2). Every activity in an effort to maintain and enhance the highest degree of public health is carried out based on non-discriminatory, participatory, and sustainable principles in the framework of forming Indonesia's human resources, as well as increasing the nation's resilience and competitiveness for national development. The provisions of the 1945 Constitution show that children are the next generation that will become leaders in the future. Consequently, healthy, intelligent and qualified children are needed to achieve national goals as referred to in the Preamble of the 1945 Constitution.

2) Article $28, \mathrm{H}$ paragraph (1). All Indonesian citizens have the right to live physically and mentally prosperously, have a place to live with a good and healthy environment, and have the right to obtain health services. This right applies to children as well. We call it a child's right. According to Law No. 35 of 2014 Article 1 Number 12, a child's right is part of

\footnotetext{
${ }^{38}$ Kementerian Kesehatan, Op.Cit., 7-8.

${ }^{39}$ H Marlia Eka Putri A.T, Op.Cit., 310

${ }^{40}$ Sulthon Miladiyanto, Ariyanti, Op.Cit., 56.
} 
human rights that must be guaranteed, protected, and fulfilled by parents, family, community, state, government, and local government. In addition, according to Law No. 39 of 1999, Article 52 paragraph (2) states the rights of the child are recognized and protected by law even in the womb. Article 1 number 2 of Law No. 35 of 2014 that child protection is all activities to guarantee and protect children and their rights so that they can live, grow, develop and participate optimally in accordance with human dignity and receive protection from violence and discrimination. Policies, businesses, and activities that guarantee the realization of child protection are based on the consideration that children are vulnerable and dependent groups. Furthermore, through the constitutional mandate, the legal provisions concerning exclusive breastfeeding are regulated through Law No. 36 of 2009.

3) Article 34 paragraph (3). Every development effort must be based on health insights in the sense that national development must pay attention to public health and is the responsibility of all parties, both the Government and the community. The state is responsible to its citizens in providing adequate health care facilities and public facilities, including also to fulfil the rights of children to get health services.

\section{c. The Law Principle in Law Number 36 of 2009 which is Related to the Exclusive Breastfeeding Program Policy}

Health development, in Law No. 36 of 2009 Article 2, is carried out based on humanity, balance, benefits, protection, respect for rights and obligations, justice, gender and nondiscriminatory and religious norms implemented through health efforts as follows:

1) The principle of humanity means exclusive breastfeeding is an action to fulfil children basic need since at an early age. Children have characteristics because they always grow and develop from the moment of conception until the end of adolescence.

2) The principle of equilibrium means that exclusive breastfeeding has consequences fulfilment of rights and obligations. Fulfilment of rights is the right of the child to obtain exclusive breastfeeding and the obligation of the mother to give it, except on medical indications, where the family, community, government and local government are obliged to support this process.

3) The principle benefits of exclusive breastfeeding means provide benefits to infants, mothers, families, and the country.

4) The principle of the protection of exclusive breastfeeding means will provide comprehensive protection for the baby. The government will also protect the achievement of citizens' rights in the exclusive breastfeeding process for babies who will receive the right to be breastfed (which is part of human rights which is the right to live healthily) and for the mother is the right to give breastmilk as part of parenting old.

5) The principle of respect means that the provision of exclusive breastfeeding provides an opportunity for babies to obtain the right to receive breastfed babies, the rights and obligations of breastfeeding mothers and support the implementation of breastfeeding for the community.

6) Fairness means exclusive breastfeeding is indiscriminate. It is given to all children, regardless of race, ethnicity, or socioeconomic status.

7) The principle of gender and non-discriminatory means exclusive breastfeeding is one gender protection for women, in terms of meeting the reproductive rights of women, in addition to menstrual and maternity leave.

8) The principle of religious norms means that exclusive breastfeeding must pay attention and respect and not distinguish the religion adhered to by the community. According to Islam, breastfeeding is in accordance with the word of Allah SWT in the Surah Al Baqarah verse 233. 


\section{d. The Purpose of Arranging Exclusive Breastfeeding}

In the Convention on the Rights of the Child Article 24, which has been ratified by Presidential Decree No. 36 of 1990, it is clearly stated the rights of children to have benefit of the highest health status, hence the state is required to take steps to minimize infant and child mortality rates, providing basic health care for infants, children, and pregnant and lactating mothers, eradicating diseases and malnutrition, ensuring all parents are informed of basic knowledge about children's. The foundation of long-term food and nutrition program policies at the national level is quite strong. This was formulated in Law No. 17 of 2007 concerning the National Long Term Development Plan (RPJPN) for 2005-2025. ${ }^{41}$ The third phase of the RPJMN for the period 2015-2019, has also provided a strong foundation for implementing the food program and improving nutrition which is one of the outcome indicators, namely increasing the prevalence of infants aged less than 6 months who receive exclusive breastfeeding to $50 \%$ in 2019.

Nowadays, the Government has issued Law No. 36 of 2009 and Government Regulation No. 33 of 2012 and the policy ten steps to successful breastfeeding (the 10 LMKM WHO revised) that accommodates exclusive breastfeeding continues to be expanded and improved coverage - in addition, realizing the increasing number of breastfeeding women working in the public sector, the Government through the Ministry of Women's Empowerment and Child Protection, the Ministry of Manpower and Transmigration and the Ministry of Health and has issued Joint Regulations of the Minister of Women Empowerment, Minister of Manpower and Transmigration and Minister of Health No: 48/Men.PP/XII/2008, PER.27/MEN/XII/2008, 1177/Menkes/PB/XII/2008 dated December 22 2008. This joint regulation is expected to be an umbrella for women workers, especially those who breastfeed to be able to breastfeed/milk breast during working time in the workplace and encourage employers to provide breastfeeding rooms that are in accordance with health standards. ${ }^{42}$

Thus, the policy and target set up by the government are to optimize the implementation of Law No. 36 of 2009 which has strict sanctions on those who intentionally block the exclusive breastfeeding program (Article 200) and severe criminal sanctions for corporations (Article 201) and the implementation of Government Regulations No. 33 of 2012, so that the number of exclusively breastfed babies reaches the target. ${ }^{43}$ Ministry of Health policy on efforts to increase breastfeeding, namely:

1) Increased breastfeeding is carried out as an effort to improve the quality of human resources which are an integral part of national development, especially in improving the quality of life.

2) Increasing breastfeeding is carried out cross-sectorally and integrated by involving the participation of the community, as well as the working community.

3) Increasing breastfeeding focuses on empowering communities and families to support pregnant women and nursing mothers in carrying out their duties according to their nature.

4) Cultivate exclusive breastfeeding behaviour for babies up to the age of 6 months.

5) Increasing breastfeeding is carried out in stages and continuously at each workplace. ${ }^{44}$

Government Regulation No. 33 of 2012 Article 3 mentions Government responsibilities in exclusive breastfeeding programs, while Article 4 and Article 5 state the responsibilities of the Provincial Government and District/City. In implementing national policies, the provincial/district/city-regions can establish regional regulations or governor/regent/mayor

\footnotetext{
${ }^{41}$ Kementerian Kesehatan RI, Kerangka Kebijakan Gerakan Sadar Gizi Dalam Rangka Seribu Hari Pertama Kehidupan (1000 HPK) (Jakarta: Kementerian Kesehatan RI, 2012), 11.

${ }^{42}$ Attchament Minister of Women's Empowerment and Child Protection Regulation No. 03 of 2010, 15-16

${ }^{43}$ Kementerian Kesehatan RI, Op.Cit., 17.

${ }^{44}$ Pusat Kesehatan Kerja Depkes RI, (n.d.), Kebijakan Departemen Kesehatan Tentang Peningkatan Pemberian Air Susu Ibu (ASI) Pekerja Wanita, Jakarta: Departemen Kesehatan RI.
} 
regulations concerning national policies. In establishing policies for exclusive breastfeeding programs in the regions, the provincial government/ districts/cities can pay attention to the capabilities and potential of human resources, capabilities and potential sources of funding, and community support. The strategy of exclusive breastfeeding programs is carried out in an integrated, tiered, and continuous manner.

Referring to this, to implement the provisions of Law No. 36 of 2009 Article 128 and 129 and Government Regulation No. 33 of 2012, Lampung Province has issued Lampung Province Regional Regulation No. 17 of 2014 and following up on the PERDA also issued Governor Regulation Number 10 in 2016. In Bandar Lampung City, the Bandar Lampung Mayor has issued a circular letter number 030/792.IV.41/2012 that released on April 18, 2012, which was addressed to Government and Private Hospitals, Health Centers and Health Service Facilities Providers, Government and Private Offices, Shopping Centers, Transport Terminals, Railway Stations, Hotels, Lodging, Recreation Areas, and Sports Buildings in Bandar Lampung City.

Furthermore, some health service facilities have been issued special written policies related to the implementation of exclusive breastfeeding programs. For instance, the Head of Kedaton Puskesmas issued Decree No. 440/603/09/2018 about Exclusive Breastfeeding Movement through the establishment of KP-ASI integrates with Asman, TOGA, and acupressure at UPT Kedaton Inpatient Health Center. ${ }^{45}$ Meanwhile, at the RSIA Belleza, the policy of exclusive breastfeeding was determined as one of the performance indicators and applied to babies born in the hospital, with the issuance of the Hospital Director's Policy that newborn babies in the RSIA Belleza work environment would only get breast milk. ${ }^{46}$

\section{e. Community Participation in Institutional Nature in Exclusive Breastfeeding}

Society has an important role in determining the success of a mother in breastfeeding and giving breast milk to her child. Community-based networks and offering support from fellow breastfeeding mothers, as well as trained breastfeeding counsellors in providing support to the mothers to start and maintain breastfeeding activities, and prevent and overcome various difficulties that may occur. Therefore, GSIYCF recommends the government to:

1) Promote the development of community-based support networks in order to ensure that proper feeding for infants and toddlers is carried out, for example, fellow support groups based on breastfeeding mothers, no medical, educational counsellor groups or fellow counsellors for nursing mothers. This network is a fellow to whom the hospital and clinic can refer to nursing mothers when they return home; and

2) Ensure that the community-based support network is not only accepted in the local health system but also actively participates in planning and providing services to mothers.

Other sources of information and support can be found as well in various forms of formal or non-formal groups or organizations, including breastfeeding support networks and childcare, clubs, and religious-based associations. Community-based support, including those provided by fellow breastfeeding mothers, breastfeeding counsellors from the general public as well as among nursing mothers, and certified breastfeeding consultants can effectively help these women to be able to provide the right food to their children. Most communities have a self-help tradition that is ready to be used as the basis for building or developing a support system that is suitable for helping families in providing proper feeding for children. Community participation in health efforts has been regulated in Law No. 36 of 2009 Article 174 and Government Regulation No. 33 of 2012 Article 37. The implementation of community support is carried out

\footnotetext{
45 Interview with the head of health care and management Program of nutrition Puskesmas Kedaton, on Wednesday, February 20, 2019.

${ }^{46}$ Interview with Dr. Kartika Malahayati, Medical Service Manager for RSIA Belleza, on Friday, March 20, 2019.
} 
in accordance with the capabilities of the available resources by referring to the ten steps to successful breastfeeding for the community.

\section{The Role of Supporting Groups Based on Fellow Mothers}

The main objective of a support group based on fellow breastfeeding mothers is to help mothers to be able to breastfeed their babies, by:

a. Providing practical and scientific information as a foundation for mothers to decide to breastfeed, and

b. Provide moral support for mothers, whenever needed, to carry out the decisions that have been taken, and thus the mothers enjoy every experience of breastfeeding they meet.

Breastfeed support groups carry out this role through group meetings, home and hospital visits, telephone services, correspondence, the distribution of literature on breastfeeding, seminars, talk shows, workshops and conferences on breastfeeding and breastfeeding at every opportunity, association, and location. Some of the support group members also conduct advocacy activities, in addition to providing breastfeeding counselling directly to mothers. This advocacy activity includes working with professional health workers to change hospital or maternity policies that prevent mothers from breastfeeding, and on the other hand, promote things that can support breastfeeding activities such as 24-hour mother and baby care. Advocacy also includes working with fellow organizations concerned with breastfeeding and breastfeeding, both locally and internationally. Furthermore is the action as an approach to government agencies and people's representatives who specifically deal with and engage in the field of maternal and child health.

The Indonesian Breastfeeding Mothers Association (AIMI) was formed in 2007. This is a non-profit organization based on a group of breastfeeding mothers to disseminate knowledge and information about breastfeeding and increasing the number of breastfeeding mothers in Indonesia. The AIMI adherences to the principle of rejecting all forms of cooperation with products that can interfere with the breastfeeding process, including baby formula, instant baby food, pacifier bottles, and pacifiers. This is one of AIMI's efforts to maintain commitment and integrity to avoid all forms of conflict of interest. Established on April 21, 2007, now AIMI exists in 16 regions/provinces, namely North Sumatra, Bangka Belitung, West Sumatra, Jambi, Lampung, Riau, South Sumatra, West Java, Central Java, Yogyakarta, East Java, Bali, West Kalimantan, East Kalimantan, South Kalimantan, and South Sulawesi. It branches in 9 municipalities/ regencies outside the provincial capital, namely Depok, Cirebon, Bekasi, Bogor, Solo, Purwokerto, Bantul, Malang, and Sorowako. ${ }^{47}$ The AIMI in Lampung was established in 2011. However, the formal legal (notary deed), as a form of institution that has legal strength, and the AIMI's statues and bylaws are still in AIMI Jakarta.

"It started with mothers who joined the ASI mailing list, meet up, with the name AFB - ASI for Baby Lampung. The overall goal of the formation of AIMI is to help increase the number of exclusive breastfeeding, because, in reality, many people consider breastfeeding to be natural, but in its implementation many difficulties, including lack of support, support systems that do not help mothers successfully breastfeed, especially there are still areas of poverty in which the number of exclusive breastfeeding is still low ".48

In addition to the breastfeeding support group in the form of a formal organization, in Indonesia, there is a breastfeeding support group which is a Community Resource Health Effort (UKBM) called the Mother Support Society Group (KP-Mothers Breastfeeding), also known as Breastfeeding Support Groups (KP -ASI). The background of the formation of this group is an effort made to improve the practice of breastfeeding by conducting counselling and

\footnotetext{
${ }^{47}$ AIMI, (n.d.), Organisasi, https://aimi-asi.org/organisasi, Acessed on November 27, 2018.

${ }^{48}$ Interviews with head of the research division of AIMI Lampung region, on Monday, February 25, 2019.
} 
counselling to mothers and families and new mothers who need to be encouraged to increase their confidence to want to breastfeed their babies. This needs to be supported by the community through the Community Support Group of Mothers (KP-Mothers of Breastfeeding). ${ }^{49}$

\section{The Role of Father-Based Support Groups}

Regarding the role of fathers, various studies have proven that breastfeeding activities are getting smoother if mothers get support and assistance from their husbands as family heads and household partners. ${ }^{50}$ The @ AyahASI movement which has been present since 2011, is one form of the public awareness campaign that husbands have a significant role in the breastfeeding process. The husband, as a spokesperson and protector consciously support his wife. $^{51}$ Until now, the @AyahASI movement inspired similar movements in more than ten cities in Indonesia. ${ }^{52}$

"The background of the formation of @AyahASI is thatwe (the initiators/founders) understand that parenting is common property and breastfeeding is too important to only be taken care of by mothers, that's why fathers should be involved in the breastfeeding process. We don't want our friends to experience the mistakes we have experienced, so we want to share information about breastfeeding and breastfeeding. "53

In the form of formal, informal and UKBM organizations, breastfeeding support groups have an essential task, such as a liaison between a nursing mother and a health worker who helps her. Breastfeeding support groups provide individual counselling services, information, support and opportunities for group discussions that make it easier for mothers to carry out breastfeeding activities and take care of their children. Breastfeeding support groups are required to have a great commitment to building and increasing the confidence of mothers to decide to breastfeed their children. ${ }^{54}$

This support group does have a different role. However, it still complements the role given by health workers and professional medical personnel. The key to the best practice of breastfeeding is to provide continuous daily support in the home environment and the local community. Two principles underlie the formation of a breastfeeding support group. The first is the emergence of awareness that breastfeeding is a positive decision concerning children's health problems, and not just a lifestyle or trend. The last is, most of the problems faced by a nursing mother are not medical problems. Hence the experienced nursing mothers can give assistance. The driving motor of a breastfeeding support group is a trained breastfeeding counsellor, who is also a mother who succeeds in breastfeeding her child and voluntarily donates her time to help other women succeed in breastfeeding their child. The counsellors are not in a position to make decisions for mothers to intervene. Instead, they help them to gain and increase the self-confidence to make their own decision on determining and doing what the best for their children is. Through breastfeeding support groups, women can further strengthen their motherhood. ${ }^{55}$

\section{Conclusion}

\footnotetext{
${ }^{49}$ Kementerian Kesehatan RI, Panduan Pembentukan dan Pembinaan Kelompok Pendukung Ibu Menyusui (Jakarta: Kementerian Kesehatan RI, 2012), 1.

${ }^{50}$ Mia Sutanto, Peran Asosiasi Masyarakat Dalam Mendukung Ibu Menyusui, (2010), 332-343, In Ikatan Dokter Anak Indonesia (IDAI), Indonesia Menyusui (Jakarta: Badan Penerbit IDAI), 337.

${ }^{51}$ Aditia Sudarto, et.al, Catatan AyahASI : Ditambah-tambahin (Tangerang: Buah Hati, 2018), 13, 27.

${ }^{52}$ AyahASI Indonesia, (n.d.), Tentang Kami, https://ayahasi.org/tentang-kami/, Acessed on March 9, 2019.

${ }^{53}$ The results of an email interview with the admin @ AyahASI, on Saturday, March 9, 2019.

${ }^{54}$ Mia, Op.Cit., 333.

${ }^{55}$ Ibid., 341.
} 
The institutional is considerably play the principal role in legal policy. They are maintaining and observing all structures and processes related to activities and efforts to realize the fulfilment of the need for legislation, moreover, as efforts to facilitate the fulfilment of the needs. The socio-legal function in fulfilling children's rights to get exclusive breastfeeding is a preventing action from any issues that can jeopardize children's safety and health through the provision of breastfeeding substitutes, encouraging increased exclusive breastfeeding and the provision of facilities in the private and public domain through providing support, place and time of breastfeeding anytime and anywhere. The exclusive breastfeeding program policy is a rule or legal norm based on provisions in Law Number 36 of 2009 about Health. The underlying legal basis is Article $28 \mathrm{~B}$ paragraph (2), Article $28 \mathrm{H}$ paragraph (1) and Article 34 paragraph (3) of the 1945 Constitution. Because it is legally binding rules so that the legal subject must fulfil the rules in the policy (in this case is the mother, family, community, government or certain institutions), if the legal subject does not comply with the applicable rules, sanctions would be imposed. Further, the exclusive breastfeeding program policy contains certain legal principles which are the soul in the formulation of the Law to realize child welfare. Forms of regulation in its policies with the issuance of Government Regulation Number 33 of 2012 concerning Exclusive Breastfeeding, which is the implementation rule of Article 129 of Law Number 36 of 2009.

\section{A. Journal}

\section{References}

A. T, Marlia Eka Putri. "TINJAUAN ATAS PERLINDUNGAN HUKUM TERHADAP HAK MENYUSUI ANAK SELAMA WAKTU KERJA DI TEMPAT KERJA BAGI PEKERJA PEREMPUAN", Fiat Justisia: Jurnal Ilmu Hukum 5, no. 3, 2011: 307-314. DOI: 10.25041/fiatjustisia.v5no3.331.

Aridiyah, Farah Okky., Rohmawati, Ninna., Ririanty, Mury. "FAKTOR-FAKTOR YANG MEMPENGARUHI KEJADIAN STUNTING PADA ANAK BALITA DI WILAYAH PEDESAAN DAN PERKOTAAN", e-Jurnal Pustaka Kesehatan 3, no. 1, 2015: 163-170.

Earlene, Felishella., Tandrajaya, Jesslyn Evelina. "SENGKETA PENGUASAAN TANAH ANTARA WARGA KAPUK POGLAR RT 07/RW 04 JAKARTA BARAT DENGAN POLDA METRO JAYA DITINJAU DARI PERSPEKTIF HAK ASASI MANUSIA", Jurnal Cepalo 3, no. 2, 2019: 55-62, DOI: 10.25041/cepalo.v3no2.1844.

Hambarrukmi, Herning., Sofiani, Triana. "KEBIJAKAN PEMBERIAN ASI EKSKLUSIF BAGI PEKERJA PEREMPUAN DI INDONESIA", MUWAZAH 8, no. 2, 2016: 268-286.

Hanafi, Yusuf. "PENINGKATAN KECERDASAN ANAK MELALUI PEMBERIAN ASI DALAM AL-QUR'AN", Mutawâtir: Jurnal Keilmuan Tafsir Hadis 2, no. 1, 2012: 27-45, DOI: 10.15642/mutawatir.2012.2.1.27-45.

Haryanti, Tuti., Nurhayati. "PENEGAKAN HUKUM HAK ASASI MANUSIA BAGI ANAK PENDERITA STUNTING”, Jurnal HAM 10, no. 2, 2019: 249-260, DOI: 10.30641/ham.2019.10.249-260.

Isra, Saldi. "PERAN MAHKAMAH KONSTITUSI DALAM PENGUATAN HAK ASASI MANUSIA DI INDONESIA", Jurnal Konstitusi 11, no. 3, 2014: 409-427, DOI: $10.31078 / \mathrm{jk} \% 25 \mathrm{x}$.

Kadir, Nurhira A. "MENELUSURI AKAR MASALAH RENDAHNYA PERSENTASE PEMBERIAN ASI EKSKLUSIF DI INDONESIA”. Jurnal Al Hikmah 15, no. 1, 2014: 106-118.

Kandioh, Frangky Benjamin., Lumolos, Johny., Kaunang, Markus. "EKSISTENSI KELOMPOK- KELOMPOK SOSIAL DALAM MELESTARIKAN NILAI-NILAI BUDAYA DI DESA KAMANGTA KECAMATAN TOMBULU KABUPATEN 
MINAHASA", Society Jurnal Ilmu Sosial dan Pengelolaan Sumber Daya Pembangunan 21, no. 1, 2016: 49-62.

Kurniawan, Zahri. Wahyudi, Ilham., Tisnanta, H S. "THE RIGHT NON-SELFINCRIMINATION AND EPISTEMOLOGY OF CRIMINAL WITNESSES," Fiat Justisia: Jurnal Ilmu Hukum 14, no. 4, 2020: 363-380, DOI: 10.25041/fiatjustisia.v14vno4.1988.

Miladiyanto, Sulthon., Ariyanti. "PERLINDUNGAN HUKUM TERHADAP HAK-HAK REPRODUKSI PEKERJA WANITA (PERSPEKTIF UNDANG-UNDANG KETENAGAKERJAAN DI INDONESIA DAN MALAYSIA)", Jurnal Panorama Hukum 2, no. 1, 2017: 53-68, DOI: 10.21067/jph.v2i1.1755.

Muyassaroh, Yanik., Amelia, Rizky., Komariyah. "FAKTOR PENGHAMBAT PEMBERIAN ASI EKSKLUSIF PADA IBU BEKERJA DI KOTA BLORA”, Jurnal Kebidanan 8, no. 1, 2018: 10-21. DOI: 10.31983/jkb.v8i1.3730.

Nurcahyo, Edy., Khuzaiyah, Siti. "PERLINDUNGAN HUKUM BAYI MELALUI PEMBERIAN ASI EKSKLUSIF DALAM PRESPEKTIF UNDANG-UNDANG NOMOR 36 TAHUN 2009 TENTANG KESEHATAN", Jurnal Cendekia Hukum 4, no. 1, 2018: 52-64, DOI: 10.33760/jch.v4i1.59.

Rahadian, Angga Sisca. "PEMENUHAN HAK ASI EKSKLUSIF DI KALANGAN IBU BEKERJA: PELUANG DAN TANTANGAN”, Jurnal Kependudukan Indonesia 9, no. 2, 2014: 109-119, DOI: 10.14203/jki.v9i2.40.

Sari, Putri Nilam. "MENINGKATKAN KESUKSESAN PROGRAM ASI EKSKLUSIF PADA IBU BEKERJA SEBAGAI UPAYA PENCAPAIAN MDGS", Jurnal Kesehatan Masyarakat Andalas 9, no. 2, 2015: 93-97, DOI: 10.24893/jkma.v9i2.194.

Setiawan, Eko., Machmud, Rizanda., Masrul. "FAKTOR-FAKTOR YANG BERHUBUNGAN DENGAN KEJADIAN STUNTING PADA ANAK USIA 24-59 BULAN DI WILAYAH KERJA PUSKESMAS ANDALAS KECAMATAN PADANG TIMUR KOTA PADANG TAHUN 2018”, Jurnal Kesehatan Andalas 7, no. 2, 2018: 275284, DOI: $10.25077 /$ jka.v7i2.813.

Sumanto, Dedi. "PENEGAKAN HUKUM DAN PEMBANGUNAN HUKUM DI INDONESIA", Jurnal Al-Mizan 10, no. 1, 2014: 121-139.

Umboh, Edelwina., Wilar, Rocky., Mantik, Max F. J. "PENGETAHUAN IBU MENGENAI MANFAAT ASI PADA BAYI", Jurnal e-Biomedik (eBM) 1, no. 1, 2013: 210-214, DOI: 10.35790/ebm.1.1.2013.1620.

Wulandari, Sri. "PERAN BADAN PERENCANAAN PEMBANGUNAN DAERAH DALAM PELAKSANAAN MUSRENBANG DI KOTA TARAKAN", eJournal Administrasi Negara 1, no. 4, 2013: 1-11.

\section{B. Book}

Ali, Zainuddin. Metode Penelitian Hukum. Jakarta: Sinar Grafika, 2016.

Asyihadie, Zaeni and Arief Rahman. Pengantar llmu Hukum. Jakarta: Rajawali Pers, 2013.

Badan Penelitian dan Pengembangan Kesehatan. Hasil Utama Riskesda Tahun 2018. Jakarta: Kementerian Kesehatan RI, 2018.

Badan Penelitian dan Pengembangan Kesehatan. Riskesdas 2013. Jakarta: Kementerian Kesehatan RI, 2013.

Gultom, Maidin. Perlindungan Hukum Terhadap Anak dan Perempuan. Bandung: Refika Aditama, 2013.

Ikatan Dokter Anak Indonesia (IDAI). Indonesia Menyusui. Jakarta: Badan Penerbit IDAI, 2010.

Kementerian Kesehatan RI. Kerangka Kebijakan Gerakan Sadar Gizi Dalam Rangka Seribu Hari Pertama Kehidupan (1000 HPK). Jakarta: Republik Indonesia, 2012. 
Kementerian Kesehatan RI. Panduan Pembentukan dan Pembinaan Kelompok Pendukung Ibu Menyusui. Jakarta: Kementerian Kesehatan RI, 2012.

Kementerian Kesehatan RI. Pokok-pokok Peraturan Pemerintah No. 33 Tahun 2012 tentang Pemberian Air Susu Ibu Eksklusif. Jakarta: Kementerian Kesehatan RI, 2012.

Monika, F.B. Buku Pintar ASI dan Menyusui. Jakarta: Noura Books, 2014.

Pollard, Maria. ASI Asuhan Berbasis Bukti. Jakarta: EGC, 2015.

Pusat Kesehatan Kerja Depkes RI. (n.d.). Kebijakan Departemen Kesehatan Tentang Peningkatan Pemberian Air Susu Ibu (ASI) Pekerja Wanita,. Jakarta: Departemen Kesehatan RI, 2010.

Roesli, Utami. Panduan Inisiasi Menyusu Dini Plus ASI Eksklusif. Jakarta: Pustaka Bunda, 2012.

Sudarto, Aditia. et.al. Catatan Ayah ASI : Ditambah-tambahin. Tangerang: Buah Hati, 2018.

Tim Nasional Percepatan Penanggulangan Kemiskinan (TNP2K). 100 kabupaten/Kota Prioritas untuk Intervensi Anak Kerdil (Stunting) Ringkasan. Jakarta: Tim Nasional Percepatan Penanggulangan Kemiskinan, 2017.

Trihono, et.al. Pendek (Stunting) di Indonesia, Masalah dan Solusinya. Jakarta: Badan Penelitian dan Pengembangan Kesehatan, 2015.

\section{Regulation}

Bandar Lampung Mayor Circular No. 030/792.IV.41/2012.

Convention on the Rights of the Child 1989

Government Regulation Number 33 of 2012.

Joint Regulation of Minister of Women, Minister of Manpower and Transmigration and the Ministry of Health No. 48 / MEN.PP / XII / 2008, PER.27 / MEN / XII / 2008 and No. 1177 / Menkes / PB / XII / 2008.

Lampung Governor Regulation Number 10 of 2016.

Lampung Province Regional Regulation Number 17 of 2014.

Law Number 35 of 2014 concerning Amendment to Law Number 23 of 2002 concerning Child Protection.

Law Number 36 of 2009 concerning Healthy.

Law Number 39 of 1999 concerning Human Rights.

Minister of Health Regulation Number 15 of 2013.

Minister of Health Regulation Number 15 of 2014.

Minister of Health Regulation Number 23 of 2014.

Minister of Health Regulation Number 25 of 2014.

Minister of Health Regulation Number 39 of 2013.

Minister of Women's Empowerment and Child Protection Regulation Number 03 of 2010.

Presidential Decree No. 36 of 1990.

The 1945 Constitution of the Unitary State of the Republic of Indonesia.

\section{Internet}

https://aimi-asi.org/organisasi, Accessed on November 27, 2018. https://ayahasi.org/tentang-kami/, Acessed on March 9, 2019. 